\title{
THE EFFECTS OF CERIUM PROMOTER ON THE PERFORMANCE OF COBALT-BASED CATALYSTS IN FISCHER TROPSCH SYNTHESIS FOR LIQUID FUEL PRODUCTION
}

\author{
Firas Khaleel Al-ZUhairi ${ }^{1}$, WafaA Abdul Kadhim ${ }^{2}$, \\ AhMed Lateef Khalaf ${ }^{3 *}$ AND MOHD HaSbi Ab RAHIM ${ }^{4}$ \\ ${ }^{I}$ Petroleum Technology Department, \\ ${ }^{2}$ Nanotechnology \& Advanced Material Research Center (NAMRC), \\ University of Technology, Baghdad, Iraq \\ ${ }^{3}$ Department of Computer Engineering Techniques, \\ Al-Ma'moon University College, Baghdad, Iraq \\ ${ }^{4}$ Faculty of Industrial Sciences \& Technology, Universiti Malaysia Pahang, \\ Gambang, Pahang, Malaysia \\ *Corresponding author: ahmed.l.khalaf@almamonuc.edu.iq
}

Received: 28 th April 2019; Accepted: $13^{\text {th }}$ March 2020; Published on-line: $4^{\text {th }}$ July 2020)

\begin{abstract}
An intensive work of Fischer-Tropsch synthesis (FTS) on a cobalt-based catalyst supported with cerium as a promoter was presented. The influence of space velocity and inlet gas feed ratio on FTS reaction performance was studied for the synthesized catalysts. Incipient wetness impregnation method was utilized to synthesis both unpromoted $\left(25 \% \mathrm{Co} / \gamma-\mathrm{Al}_{2} \mathrm{O}_{3}\right)$ and cerium promoted $\left(1 \% \mathrm{Ce}-25 \% \mathrm{Co} / \gamma-\mathrm{Al}_{2} \mathrm{O}_{3}\right)$ catalysts. The proposed catalysts were examined by $\mathrm{N}_{2}$ adsorption and temperatureprogramed reduction (TPR). The performance of Ce-promoted and unpromoted cobaltbased catalysts in FTS was assessed in terms of activity and selectivity to desired products $\left(\mathrm{C}_{5+}\right)$. The obtained results revealed that the addition of cerium by impregnation notably favours the reducibility of cobalt oxides by reducing the reduction temperature. In addition, the promoted catalysts exhibited higher activity and selectivity toward desired products at low space velocity and high inlet gas feed ratio as compared with the unpromoted catalysts. In conclusion, a cerium based cobalt catalyst considered as a suitable candidate to be used in gas to the liquid conversion process.
\end{abstract}

ABSTRAK: Kajian intensif sintesis Fischer-Tropsch (FTS) adalah tentang pemangkin berasas kobalt bersama penggalak cerium. Pengaruh tindak balas FTS pada halaju ruang dan nisbah suapan gas masuk dikaji menggunakan pemangkin yang disintesis. Kaedah impregnasi insipien basah telah digunakan bagi mensintesis pemangkin bukan penggalak $\left(25 \% \mathrm{Co} / \gamma-\mathrm{Al}_{2} \mathrm{O}_{3}\right)$ dan penggalak cerium $\left(1 \% \mathrm{Ce}-25 \% \mathrm{Co} / \gamma-\mathrm{Al}_{2} \mathrm{O}_{3}\right)$. Pemangkin ini diuji dengan penjerapan $\mathrm{N}_{2}$ dan pengurangan suhu terprogram (TPR). Hasil tindak balas penggalak-Ce dan bukan penggalak berasas kobalt dalam FTS diperiksa dari segi aktiviti dan pemilihan hasil $\left(\mathrm{C}_{5+}\right)$. Tindak balas menunjukkan dengan penambahan cerium melalui kaedah impregnasi dengan ketara mengurangkan kobalt oksida bersama pengurangan suhu. Di samping itu, pemangkin penggalak menunjukkan aktiviti dan pemilihan ke arah hasil pada halaju ruang dan nisbah suapan gas masuk yang tinggi berbanding dengan pemangkin bukan penggalak. Kesimpulan, pemangkin kobalt berasas cerium dianggap sesuai sebagai pemangkin sintesis bagi digunakan dalam proses penukaran gas ke cecair.

KEYWORDS: catalyst, cerium promoter, Fischer-Tropsch synthesis, GTL, syngas; 


\section{INTRODUCTION}

Over the past few decades, natural gas has been considered a plentiful and cleanest natural fuel that should be altered to liquid form to prevent safety hazards and to reduce transportation costs [1]. Natural gas, methane $\left(\mathrm{CH}_{4}\right)$ is commonly employed to produce synthesized gas (syngas) via different techniques, such as partial oxidation [2], steam reforming [3], and auto-thermal reforming [4].

Recently, the gas-to-liquid technique (GTL) has been considered one of the most efficient processes that is mainly used to convert natural gas into a syngas intermediate through a Fischer-Tropsch (FT) synthesis technology [5]. In general, the GTL process produces oil crudes that contain different fractions of useful hydrocarbons that can be amended and segregated to different types of necessary transportation sector fuels [6], in the presence of solid catalysts.

Because of their high $\mathrm{C}_{5+}$ selectivity, excellent activity, and ability to work at low operating temperatures (between 200 and $250{ }^{\circ} \mathrm{C}$ ), Co-based catalysts are in the limelight recently as an effective catalyst for attaining heavy hydrocarbons in FT synthesis [7,8]. Thus, it is of a great necessity to improve the efficiency of Co-based catalysts. Many researches have demonstrated that adding different promoters and loadings to the catalyst assists in improving the selectivity and activity of the catalyst towards $\mathrm{C}_{5+}$ contents. Guo et al. [9] reported that adding a small amounts of Lanthanum to the $\mathrm{Co} / \gamma-\mathrm{Al}_{2} \mathrm{O}_{3}$ catalyst could enhance the performance of the catalyst in terms of selectivity, activity, and Co reducibility to heavy hydrocarbons. Co reducibility was significantly increased by adding different loading of silver to the Co-based catalyst [10]. Furthermore, the addition of silver helps in decreasing the reduction temperatures by up to $100^{\circ} \mathrm{C}$ and increasing the Co reduction, dispersion, and electronic properties.

Another study by Pedersen et al. [11] employed manganese (Mn) as a promoter for a Co-based catalyst supported by $\gamma-\mathrm{Al}_{2} \mathrm{O}_{3}$. They found that $\mathrm{Mn}$ enhanced the intrinsic Co catalyst activity, Co dispersion, and selectivity to $\mathrm{C}_{5+}$ species due to its stable effect on the adsorption of $\mathrm{CO}, \mathrm{C}, \mathrm{H}, \mathrm{O}, \mathrm{CHX}$, thereby decreasing the $\mathrm{CO}$ dissociation barrier. Rare earth elements were also utilized to improve the performance of the Co-based catalyst supported by $\mathrm{Al}_{2} \mathrm{O}_{3}, \mathrm{SiO}_{2}, \mathrm{TiO}_{2}, \mathrm{ZrO}_{2}$, and CNTs $[12,13]$.

Among all the discussed promoters, Co-based catalysts promoted with Cerium (Ce) attained excellent performance in FT synthesis technology due to its ability to facilitate the dissociation of $\mathrm{CO}$, weaken the interaction between support and $\mathrm{Co}$ and improve the activity, $\mathrm{C}^{5+}$ selectivity and the olefin/paraffin ratio of the Co-based catalyst [13-15]. Although many studies have been conducted on $\mathrm{Ce}$ as a promoter for Co-based catalysts, there are great opportunities in further investigating the influence of reaction conditions on the cerium- promoted cobalt-based catalyst in FTS reactions.

Herein, we thoroughly study and evaluate the effects of reaction conditions (space velocity and $\mathrm{H}_{2} / \mathrm{CO}$ ratio) on the cerium-promoted Co-based catalyst in terms of FTS activity and product selectivity. The developed catalyst shows excellent results as compared with those of the un-promoted cobalt-based catalyst.

\section{MATERIALS AND METHODS}

\subsection{Catalysts Preparation}

Incipient wetness impregnation method was employed to synthesize the Co-based catalysts supported by $\gamma-\mathrm{Al}_{2} \mathrm{O}_{3}$ (Axens) according to the method reported by Trépanier et 
al. [16]. Initially, the support $\left(\gamma-\mathrm{Al}_{2} \mathrm{O}_{3}\right)$ was calcined in airflow at $500{ }^{\circ} \mathrm{C}$ for $4 \mathrm{~h}$. After cooling down the temperature to room temperature $\left(25^{\circ} \mathrm{C}\right)$, sequential impregnation with continuous stirring in aqueous solutions of Cobalt (II) nitrate hexahydrate $\left(\mathrm{Co}\left(\mathrm{NO}_{3}\right)_{2} \cdot 6 \mathrm{H}_{2} \mathrm{O}\right)$ was performed at ambient temperature. Then, $25 \%$ of Co by weight was laden to the mixture and left to dry for $12 \mathrm{~h}$ at $110{ }^{\circ} \mathrm{C}$ and then calcined at $400{ }^{\circ} \mathrm{C}$ for $6 \mathrm{~h}$ beneath airflow with a degree of temperature increase $2^{\circ} \mathrm{C} /$ min to attain $25 \mathrm{Co} / \gamma-\mathrm{Al}_{2} \mathrm{O}_{3}$ reduced catalyst.

To obtain the Ce promoted catalyst, 1 wt. $\%$ of Ce promoter was added to $25 \mathrm{Co} / \gamma$ $\mathrm{Al}_{2} \mathrm{O}_{3}$ dried un-calcined catalyst by the co-impregnation in an aqueous solution of Cerium nitrate hexahydrate $\left(\mathrm{Ce}\left(\mathrm{NO}_{3}\right)_{2} \cdot 6 \mathrm{H}_{2} \mathrm{O}\right)$ and dried overnight for $12 \mathrm{~h}$ at $110^{\circ} \mathrm{C}$. Later, the catalyst was calcined at $400{ }^{\circ} \mathrm{C}$ for $6 \mathrm{~h}$ with a heating rate of $2{ }^{\circ} \mathrm{C} / \mathrm{min}$ under airflow. The developed catalysts were labelled as $\mathrm{Co}_{0}$ and $\mathrm{Co}_{1}$ representing unpromoted and $\mathrm{Ce}$ promoted Co-based catalysts, respectively.

\subsection{Catalyst Characterization}

The calcined prepared catalysts were characterized by temperature-programed reduction (TPR) and $\mathrm{N}_{2}$ physisorption. The temperature-programed reductions were accomplished to decide the reducibility of metal oxides to metallic using a TP-5000 analyser fitted with a quartz tubular reactor and TCD. A $50 \mathrm{mg}$ of each sample was exposed to a continuous argon gas flow at rate of $1.8 \mathrm{~L} / \mathrm{h}$ containing $5 \%$ of $\mathrm{H}_{2}$ with heating temperature ranging from $25^{\circ} \mathrm{C}$ to $900{ }^{\circ} \mathrm{C}$ with increments of $10{ }^{\circ} \mathrm{C}$ per min.

$\mathrm{N}_{2}$ physisorption isotherm analysis was done using the Micromeritics ASAP-2020 system, to estimate the BET surface area, pore-volume, and the average pore radius for the $\gamma-\mathrm{Al}_{2} \mathrm{O}_{3}$ and catalysts.

\subsection{Fischer-Tropsch Reaction (FTR)}

As aforementioned, the FTR process was utilized to convert synthesized gas to liquid fuel (high molecules weight hydrocarbons). The activity and selectivity of the developed catalysts were investigated in a fixed-bed flow reactor made from a stainless steel metal with internal diameter of $10 \mathrm{~mm}$. Two grams of the promoted and unpromoted Co-based was loaded in the centre of the reactor and fixed between two quartz beads, then heated under argon gas to reduction temperature, the reduction was conducted by $\left(5 \% \mathrm{H}_{2}-95 \% \mathrm{Ar}\right)$ gas mixture to convert the forms of metal from oxide to the metallic. After finishing the reduction, the reactant gases mixtures $\left(\mathrm{H}_{2}\right.$ and $\left.\mathrm{CO}\right)$ were introduced to the reactor with a desired flow rate using a mass flow controller (Brooks 5850) fitted with a PID controller.

The FT reactions were conducted at a temperature of $230{ }^{\circ} \mathrm{C}$ and pressure of 15 bar with different space velocity (SV) in the range of $2-8 \mathrm{~L} / \mathrm{h} . \mathrm{g}_{\text {cat. }}$ (with increments of 2 ) and different feed gas ratio $\left(\mathrm{H}_{2} / \mathrm{CO}\right)$ of 1 to 2 (with increments of 0.5 ). The output stream from the reactor was lowered to atmospheric pressure by a control valve (BPR) and then went over two traps. The first one was at $100{ }^{\circ} \mathrm{C}$ and the other was $0{ }^{\circ} \mathrm{C}$ to condense the products. The compositions of products in a gas and liquid phase were analysed online and off-line using a gas chromatograph (GC-Shimadzu-2014) equipped with (TCD and FID) and Varian CP 3800 equipped with FID, respectively.

\section{RESULTS AND DISCUSSION}

\subsection{Catalyst Characterization}

The TPR profiles for the unpromoted $\left(25 \% \mathrm{Co} / \gamma-\mathrm{Al}_{2} \mathrm{O}_{3}\right)$ and promoted $(1 \% \mathrm{Ce}-$ $\left.25 \% \mathrm{Co} / \gamma-\mathrm{Al}_{2} \mathrm{O}_{3}\right)$ calcined catalysts are illustrated in Fig. 1. Three reduction peaks are 
clearly observed for the un-promoted Co-based catalyst. The reduction of $\mathrm{Co}_{3} \mathrm{O}_{4}$ to $\mathrm{CoO}$ $\left(\mathrm{Co}^{3+} \rightarrow \mathrm{Co}^{2+}\right)$ and $\mathrm{CoO}$ to $\mathrm{Co}$ metal $\left(\mathrm{Co}^{2+} \rightarrow \mathrm{Co}^{0}\right)$ can be allocated at $350{ }^{\circ} \mathrm{C}$ and $577{ }^{\circ} \mathrm{C}$, respectively [17]. While, the weak peak noticed around $702{ }^{\circ} \mathrm{C}$ can be attributed to the reduction of cobalt aluminate compounds [18]. On the other hand, the catalyst promoting with $1 \%$ Ce has robustly influenced the TPR profile, as revealed in Fig. 1, where the first and second peaks obviously shifted to lower temperature, at $252{ }^{\circ} \mathrm{C}$ and $527{ }^{\circ} \mathrm{C}$, respectively, due to the significant easy reduction of $\mathrm{CoO}$ to $\mathrm{Co}$ metal along with the low interaction between $\mathrm{Co}$ ions and the $\mathrm{Al}_{2} \mathrm{O}_{3}$ support $[19,20]$. As a result, the third peak related to cobalt aluminate compounds observed in the un-promoted catalyst disappeared. In addition, the TPR outcomes confirmed that the selected reduction parameters $\left(5 \% \mathrm{H}_{2}\right.$ $95 \% \mathrm{Ar}$ ) mixture by rate of flow $1.8 \mathrm{~L} / \mathrm{h}$ at $570{ }^{\circ} \mathrm{C}$ for $10 \mathrm{~h}$ ) were appropriate for reducing the cobalt oxides into cobalt metal in- suite apparatus prior to the FT reaction.

Table 1 listed the results of single point pore volume, BET surface area (SA) and pore size for the calcined support $\left(\gamma-\mathrm{Al}_{2} \mathrm{O}_{3}\right), \mathrm{Co}_{0}$, and $\mathrm{Co}_{1}$ catalysts. From the table, it can be noticed that the SA of $\gamma-\mathrm{Al}_{2} \mathrm{O}_{3}, \mathrm{Co}_{0}$, and $\mathrm{Co}_{1}$ were found to be $145,95.2$ and $94.6 \mathrm{~m}^{2} / \mathrm{g}$, respectively.

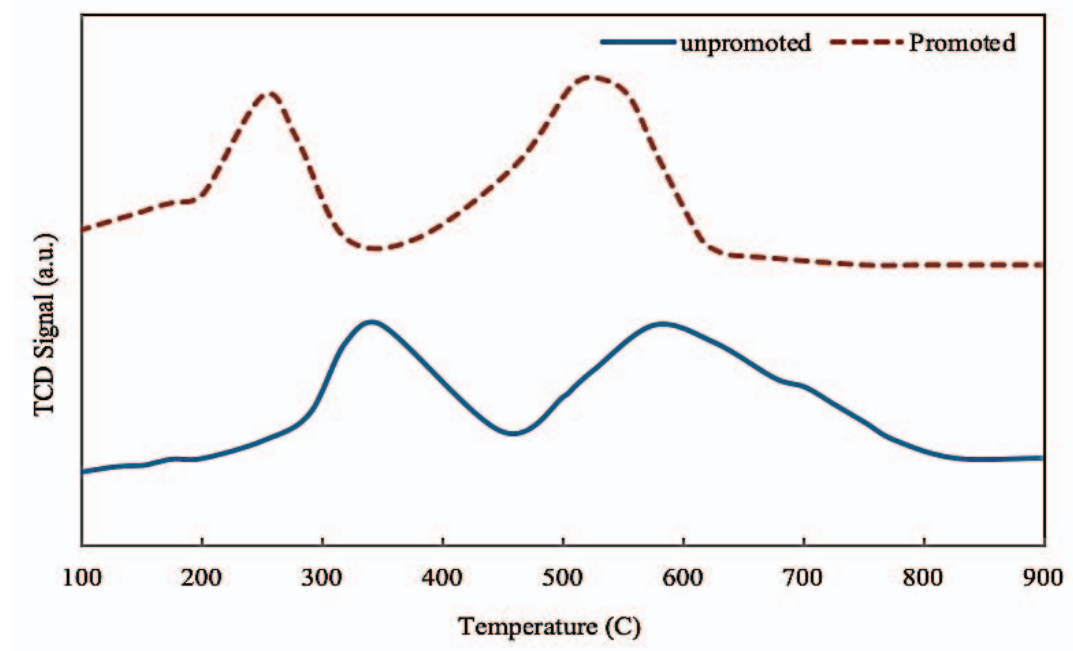

Fig. 1: TPR profiles for the un-promoted $\left(25 \% \mathrm{Co} / \gamma-\mathrm{Al}_{2} \mathrm{O}_{3}\right)$ and promoted $\left(1 \% \mathrm{Ce}-25 \% \mathrm{Co} / \gamma-\mathrm{Al}_{2} \mathrm{O}_{3}\right)$ calcined catalysts.

Table 1: BET surface area and pore volume for the developed catalysts

\begin{tabular}{lllcc}
\hline Catalyst & Symbol & $\begin{array}{l}\text { BET } \\
\left(\mathbf{m}^{2} / \mathbf{g}\right)\end{array}$ & $\begin{array}{c}\text { SA pore volume } \\
\left(\mathbf{c m}^{3} / \mathbf{g}\right)\end{array}$ & $\begin{array}{c}\text { pore size } \\
(\mathbf{n m})\end{array}$ \\
\hline$\gamma-\mathrm{Al}_{2} \mathrm{O}_{3}$ & - & 145 & 0.542 & 6.8 \\
$25 \% \mathrm{Co} / \gamma-\mathrm{Al}_{2} \mathrm{O}_{3}$ & $\mathrm{Co}_{0}$ & 95.2 & 0.276 & 4.9 \\
$1 \% \mathrm{Ce}-25 \% \mathrm{Co} / \gamma-\mathrm{Al}_{2} \mathrm{O}_{3}$ & $\mathrm{Co}_{1}$ & 94.6 & 0.265 & 4.7 \\
\hline
\end{tabular}

SA for the support was $145 \mathrm{~m}^{2} / \mathrm{g}$ which plunged to $95.2 \mathrm{~m}^{2} / \mathrm{g}$ for the unpromoted catalyst, the $25 \%$ of $\mathrm{Co}$ corresponds to $34 \% \mathrm{Co}_{3} \mathrm{O}_{4}$. According to the obtained cobalt oxide percentage, the theoretical value of the BET surface area catalyst was approximately $95.6 \mathrm{~m}^{2} / \mathrm{g}$ for the un-promoted catalyst. The theoretical and experimental BET surface area values were more closed owing to the minimum pore plugged by cobalt species [21]. Adding the Ce promoter causes a small decrement in the surface area. In addition, the pore volume and pore size for the $\gamma-\mathrm{Al}_{2} \mathrm{O}_{3}$ were $0.542 \mathrm{~cm}^{3} / \mathrm{g}$ and $6.8 \mathrm{~nm}$, respectively, that 
decreases to $0.276 \mathrm{~cm}^{3} / \mathrm{g}$ and $4.9 \mathrm{~nm}$, accordingly, for $\mathrm{Co}_{0}$. Pore volume and pore size were slightly altered in $\mathrm{Co}_{1}$. These results are in good agreement with the results reported by Gnanamani et al. [22].

\subsection{Fischer-Tropsch Synthesis}

Production of liquid fuels by FT synthesis process is considered as one of the most important techniques used to tackle the problem of fuel shortage in the transport sector [23]. To investigate the influences of space velocity and inlet feed ratio $\left(\mathrm{H}_{2} / \mathrm{CO}\right)$ on the activity of unprompted and Ce promoted catalysts and their selectivity toward liquid fuels production, number of experiments of Fischer-Tropsch reaction were conducted at a temperature of $230^{\circ} \mathrm{C}$, pressure of 15 bar, and different space velocity and inlet feed ratios $\left(\mathrm{H}_{2} / \mathrm{CO}\right)$. After steady-state condition of about 8 to $9 \mathrm{~h}$, the percentage of carbon monoxide conversion $\left(\% \mathrm{X}_{\mathrm{CO}}\right)$ and product selectivity $(\%)$ were examined.

\subsubsection{Influence of Space Velocity on Catalyst Performance}

Figure 2 shows that the $\mathrm{CO}$ conversion $\left(\% \mathrm{X}_{\mathrm{CO}}\right)$ as a function of space velocities of the developed catalysts $\left(\mathrm{Co}_{0}\right.$ and $\left.\mathrm{Co}_{1}\right)$ ranges from 2 to $8 \mathrm{~L} / \mathrm{h}$. g gat. with different $\mathrm{H}_{2} / \mathrm{CO}$ ratios between 1 and 2 for each SV at operating temperature and applied pressure of 230 ${ }^{\circ} \mathrm{C}$ and 15 bar, respectively. The obtained results demonstrated that the $\mathrm{CO}$ conversion sharply decreased when SV increased thereby, the residence time of reaction decreased. Thus, $\mathrm{CO}$ conversion and chain growth decrease, which assures the rapid increase in the formation of low molecular weight hydrocarbons $\left(\mathrm{CH}_{4}\right.$ and $\left.\mathrm{C}_{2}-\mathrm{C}_{4}\right)$ and the decrease in production of high molecular weight hydrocarbons $\left(\mathrm{C}_{5+}\right)[24]$.

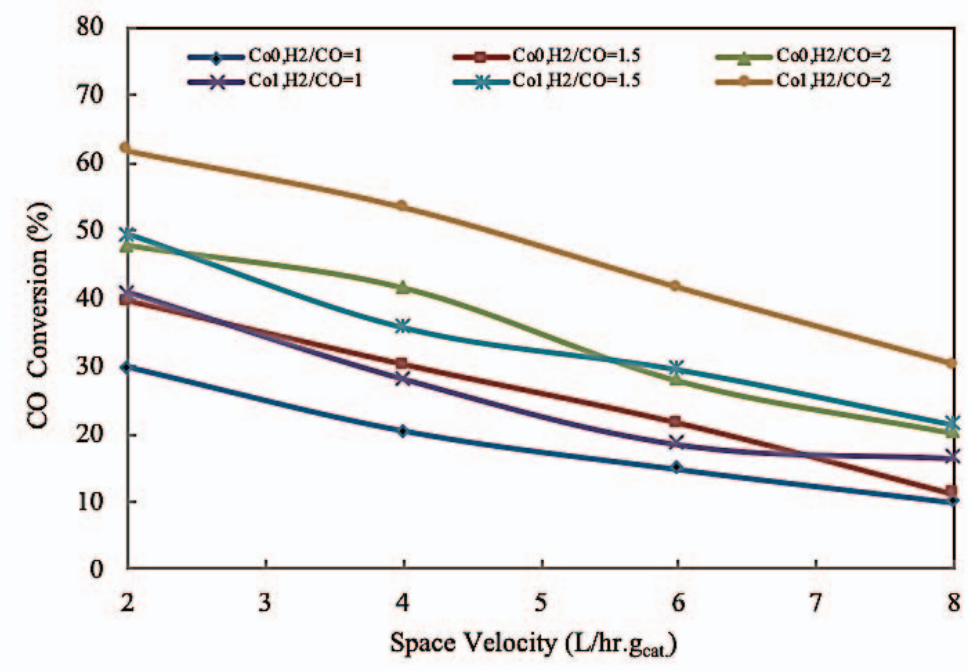

Fig. 2: Effect of space velocity on carbon monoxide conversion for the Ce-promoted and unpromoted cobalt catalysts at $\mathrm{P}=15$ bar, $\mathrm{T}=230^{\circ} \mathrm{C}$, and $\mathrm{H}_{2} / \mathrm{CO}=1,1.5$, and 2 .

The selectivity of the developed catalysts $\left(\mathrm{Co}_{0}\right.$ and $\left.\mathrm{Co}_{1}\right)$ toward $\mathrm{CH}_{4}, \mathrm{C}_{2}-\mathrm{C}_{4}$ hydrocarbons, $\mathrm{C}_{5+}$, and $\mathrm{CO}_{2}$ are demonstrated in Fig. 3(a-d). It is evident that the product selectivity of both catalysts against $\mathrm{CH}_{4}, \mathrm{C}_{2}-\mathrm{C}_{4}$ hydrocarbons, and $\mathrm{CO}_{2}$ increased proportionally with SV while the desired product $\left(\mathrm{C}_{5+}\right)$ decreased. This is because an increase in SV leads to a significant decrease in the residence time of reaction, thereby decreasing the $\mathrm{CO}$ conversion, which is in agreement with the results reported in [24]. Figure 3a shows that the selectivity of $\mathrm{Co}_{0}$ and $\mathrm{Co}_{1}$ toward $\mathrm{CO}_{2}$ were very small $(<3)$. This can be attributed to the little activity of water-gas shift mainly obtained by the Co 
based catalyst $[25,26]$. Furthermore, the promoted Co-based catalysts exhibited an excellent Co conversion and $\mathrm{C}_{5+}$ selectivity by decreasing the $\mathrm{SV}$ due to the presence of Ce promoter which aids in increasing the amount of chemisorbed hydrogen and weakening the strong bond of $\mathrm{Co}-\mathrm{H}$ [27]. Table 2 summarized the obtained results.

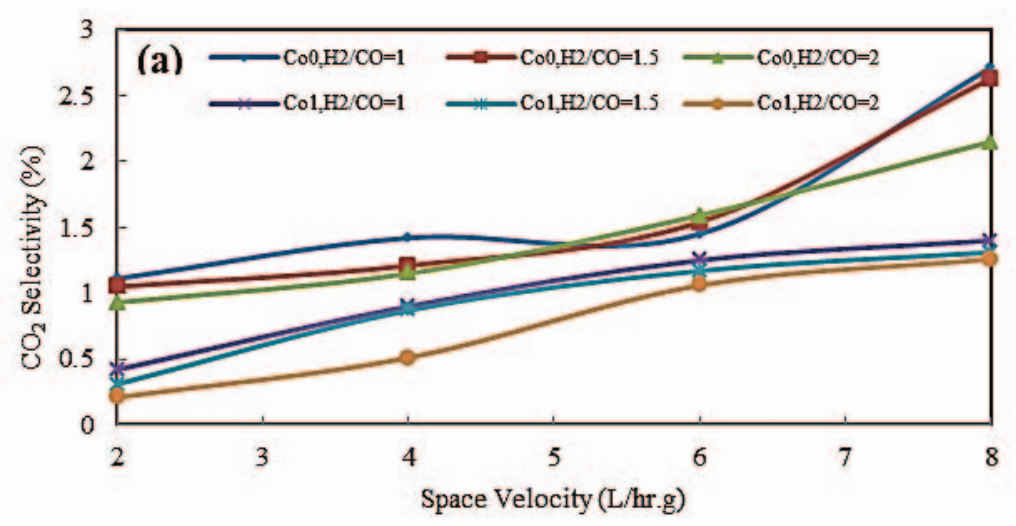

Fig. 3: (a) Effect of $\mathrm{SV}$ on $\mathrm{CO}_{2}$ selectivity for the Ce-promoted and unpromoted cobalt catalysts at $\mathrm{P}=15$ bar, $\mathrm{T}=230^{\circ} \mathrm{C}$ and $\mathrm{H}_{2} / \mathrm{CO}$ ranging from 1 to 2 .

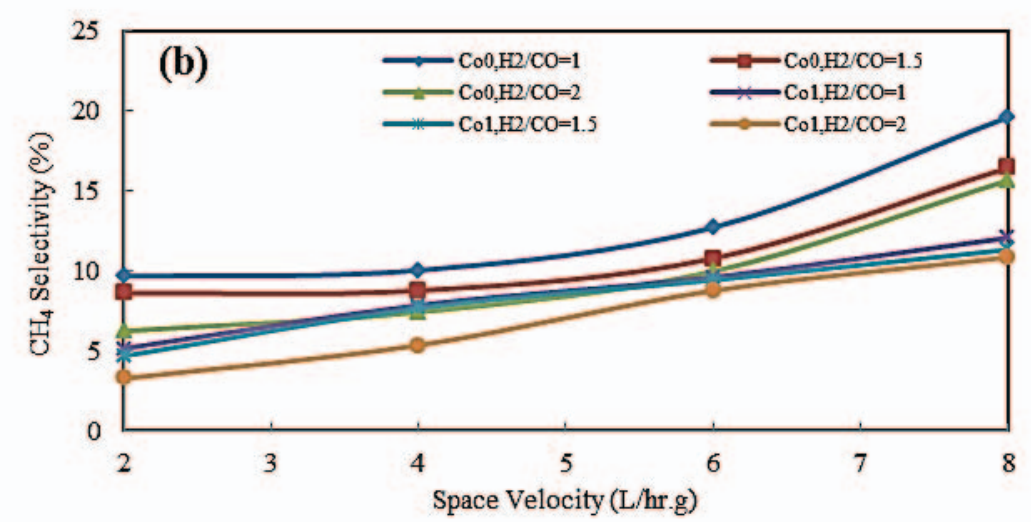

Fig. 3: (b) Effect of $\mathrm{SV}$ on $\mathrm{CH}_{4}$ selectivity for the Ce-promoted and unpromoted cobalt catalysts at $\mathrm{P}=15$ bar, $\mathrm{T}=230^{\circ} \mathrm{C}$ and $\mathrm{H}_{2} / \mathrm{CO}$ ranging from 1 to 2 .

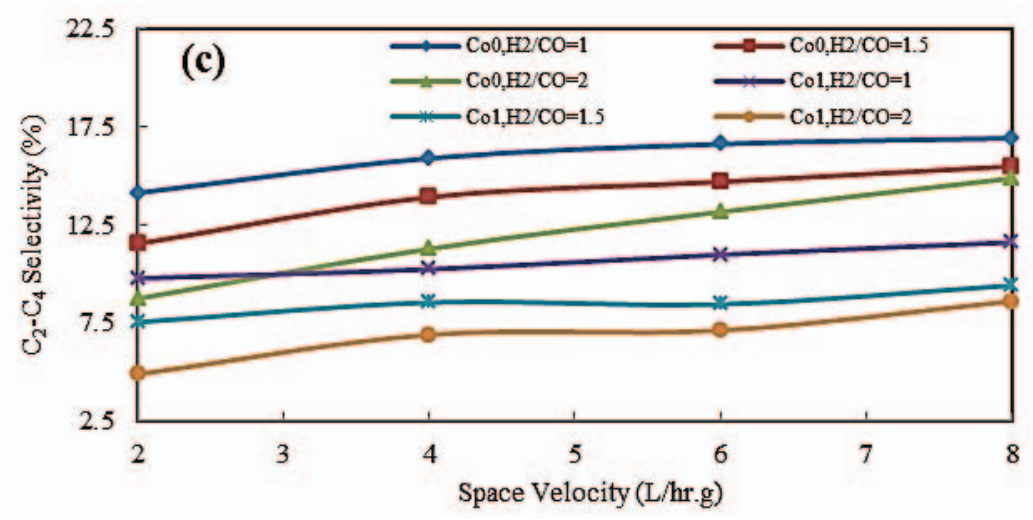

Fig. 3: (c) Effect of $\mathrm{SV}$ on $\mathrm{C}_{2}-\mathrm{C}_{4}$ selectivity for the Ce-promoted and unpromoted cobalt catalysts at $\mathrm{P}=15$ bar, $\mathrm{T}=230^{\circ} \mathrm{C}$ and $\mathrm{H}_{2} / \mathrm{CO}$ ranging from 1 to 2 . 


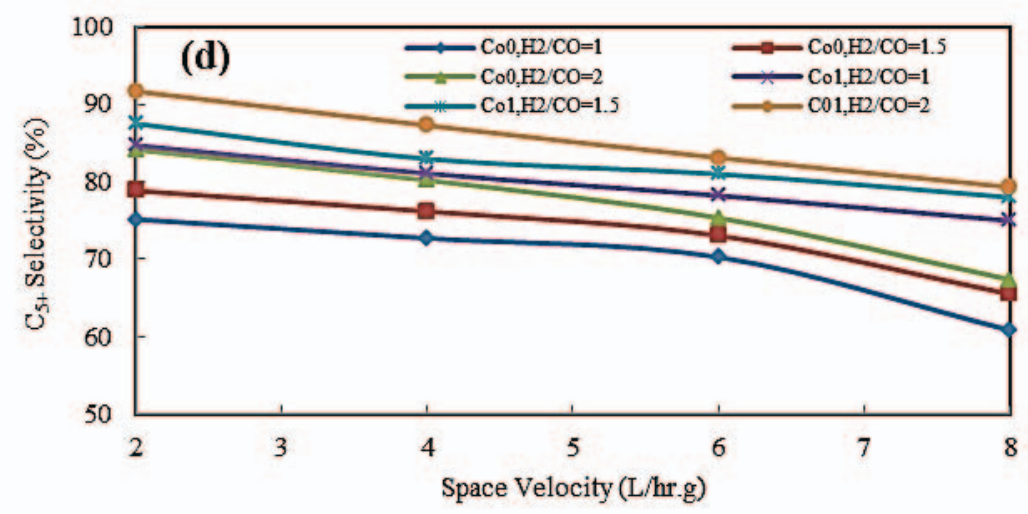

Fig. 3: (d) Effect of SV on $\mathrm{C}_{5}+$ selectivity for the Ce-promoted and unpromoted cobalt catalysts at $\mathrm{P}=15$ bar, $\mathrm{T}=230^{\circ} \mathrm{C}$ and $\mathrm{H}_{2} / \mathrm{CO}$ ranging from 1 to 2 .

\subsubsection{Influence of Inlet Feed Ratio ( $\left.\mathrm{H}_{2} / \mathrm{CO}\right)$ on Catalyst Performance}

The effect of inlet feed ratio $\left(\mathrm{H}_{2} / \mathrm{CO}\right)$ on the developed catalysts $\left(\mathrm{Co}_{0}\right.$ and $\left.\mathrm{Co}_{1}\right)$ has been thoroughly investigated in terms of \%XCO and selectivity at operating temperature of $230^{\circ} \mathrm{C}$ and under a pressure of 15 bar with different SV, as shown in Fig. 4 and Fig. 5 and listed in Table 2.

Table 2: Catalytic performance of Co-based catalysts during CO hydrogenation

\begin{tabular}{|c|c|c|c|c|c|c|c|}
\hline \multirow[t]{2}{*}{ Catalyst } & \multirow{2}{*}{$\begin{array}{c}\text { SV } \\
\text { (L/hr. gcat.) }\end{array}$} & \multirow[t]{2}{*}{$\mathrm{H}_{2} / \mathrm{CO}$ ratio } & \multirow[t]{2}{*}{$\% X_{\text {CO }}$} & \multicolumn{4}{|c|}{ \%Selectivity } \\
\hline & & & & $\mathrm{CH}_{4}$ & $\mathrm{C}_{2}-\mathrm{C}_{4}$ & $\mathrm{C}_{5}+$ & $\mathrm{CO}_{2}$ \\
\hline \multirow{12}{*}{$\begin{array}{c}25 \% \mathrm{Co} / \gamma-\mathrm{Al}_{2} \mathrm{O}_{3} \\
\left(\mathrm{Co}_{0}\right)\end{array}$} & 2 & 1 & 29.8 & 9.65 & 14.12 & 75.12 & 1.11 \\
\hline & & 1.5 & 39.5 & 8.6 & 11.53 & 78.82 & 1.05 \\
\hline & & 2 & 47.8 & 6.23 & 8.74 & 84.1 & 0.93 \\
\hline & 4 & 1 & 20.4 & 10.02 & 15.88 & 72.68 & 1.42 \\
\hline & & 1.5 & 30.2 & 8.75 & 13.9 & 76.14 & 1.21 \\
\hline & & 2 & 41.5 & 7.41 & 11.27 & 80.17 & 1.15 \\
\hline & 6 & 1 & 14.7 & 12.7 & 15.6 & 70.25 & 1.45 \\
\hline & & 1.5 & 21.6 & 10.76 & 14.68 & 73.02 & 1.54 \\
\hline & & 2 & 27.8 & 9.95 & 13.15 & 75.31 & 1.59 \\
\hline & 8 & 1 & 9.8 & 19.58 & 16.9 & 60.81 & 2.71 \\
\hline & & 1.5 & 11.2 & 16.42 & 15.47 & 65.48 & 2.63 \\
\hline & & 2 & 20.1 & 15.64 & 14.86 & 67.35 & 2.15 \\
\hline \multirow{12}{*}{$\begin{array}{c}1 \% \mathrm{Ce}-25 \% \mathrm{Co} / \gamma-\mathrm{Al}_{2} \mathrm{O}_{3} \\
\left(\mathrm{Co}_{1}\right)\end{array}$} & 2 & 1 & 40.8 & 5.13 & 9.77 & 84.68 & 0.42 \\
\hline & & 1.5 & 49.4 & 4.67 & 7.54 & 87.48 & 0.31 \\
\hline & & 2 & 61.9 & 3.26 & 4.89 & 91.64 & 0.21 \\
\hline & 4 & 1 & 28.1 & 7.84 & 10.23 & 81.03 & 0.9 \\
\hline & & 1.5 & 35.7 & 7.66 & 8.54 & 82.93 & 0.87 \\
\hline & & 2 & 53.5 & 5.34 & 6.9 & 87.25 & 0.51 \\
\hline & 6 & 1 & 18.5 & 9.59 & 10.97 & 78.19 & 1.25 \\
\hline & & 1.5 & 29.5 & 9.41 & 8.45 & 80.97 & 1.17 \\
\hline & & 2 & 41.6 & 8.75 & 7.12 & 83.07 & 1.06 \\
\hline & 8 & 1 & 16.5 & 12.05 & 11.6 & 74.95 & 1.4 \\
\hline & & 1.5 & 21.4 & 11.31 & 9.41 & 77.97 & 1.31 \\
\hline & & 2 & 30.2 & 10.84 & 8.61 & 79.29 & 1.26 \\
\hline
\end{tabular}




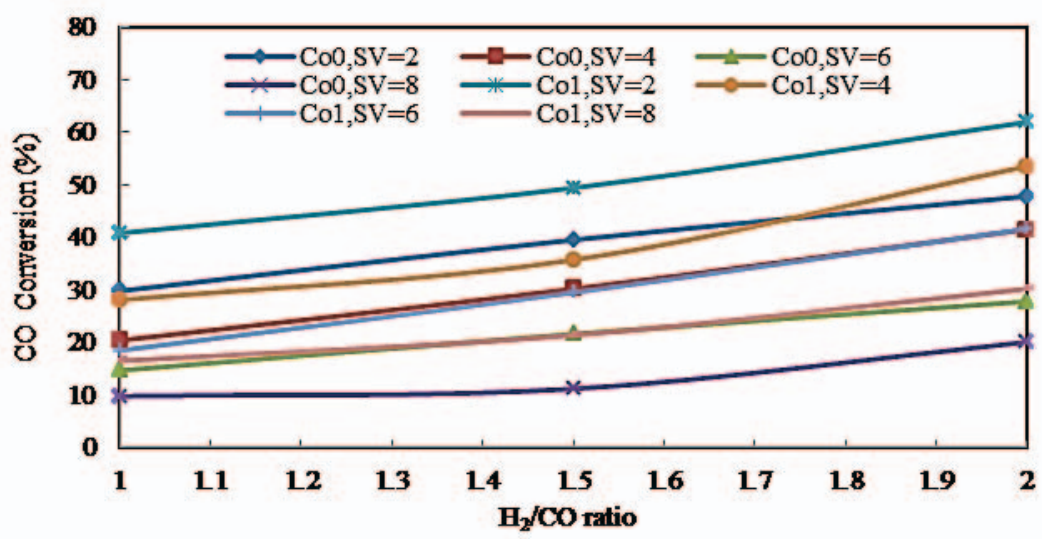

Fig. 4: Effect of $\mathrm{H}_{2} / \mathrm{CO}$ ratio on $\mathrm{CO}$ conversion for the Ce-promoted and unpromoted cobalt catalysts at $\mathrm{P}=15$ bar, $\mathrm{T}=230^{\circ} \mathrm{C}$ and $\mathrm{SV}=2,4,6$ and $8 \mathrm{~L} / \mathrm{h}$. g cat.

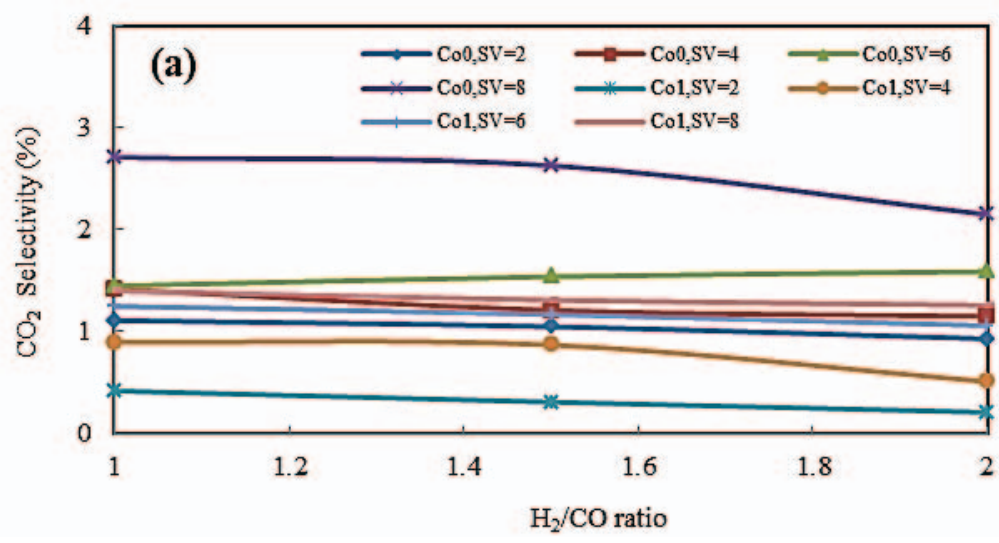

Fig. 5: (a) Effect of $\mathrm{H}_{2} / \mathrm{CO}$ ratio on $\mathrm{CO}_{2}$ selectivity for the Ce-promoted and unpromoted cobalt catalysts at $\mathrm{P}=15$ bar, $\mathrm{T}=230{ }^{\circ} \mathrm{C}$ and $\mathrm{SV}=2,4,6$ and $8 \mathrm{~L} / \mathrm{h}$. g cat.

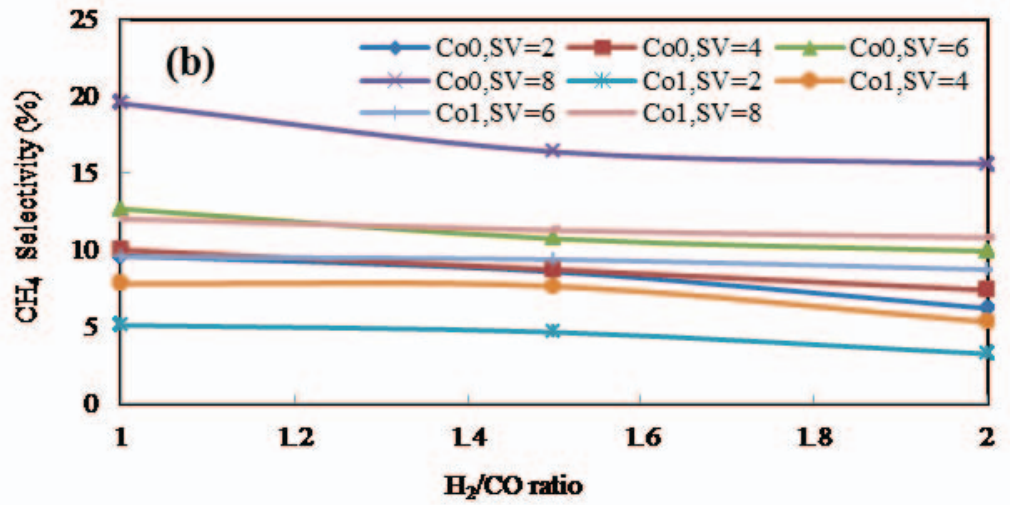

Fig. 5: (b) Effect of $\mathrm{H}_{2} / \mathrm{CO}$ ratio on $\mathrm{CH}_{4}$ selectivity for the Ce-promoted and unpromoted cobalt catalysts at $\mathrm{P}=15$ bar, $\mathrm{T}=230^{\circ} \mathrm{C}$ and $\mathrm{SV}=2,4,6$ and $8 \mathrm{~L} / \mathrm{h}$. g cat. 


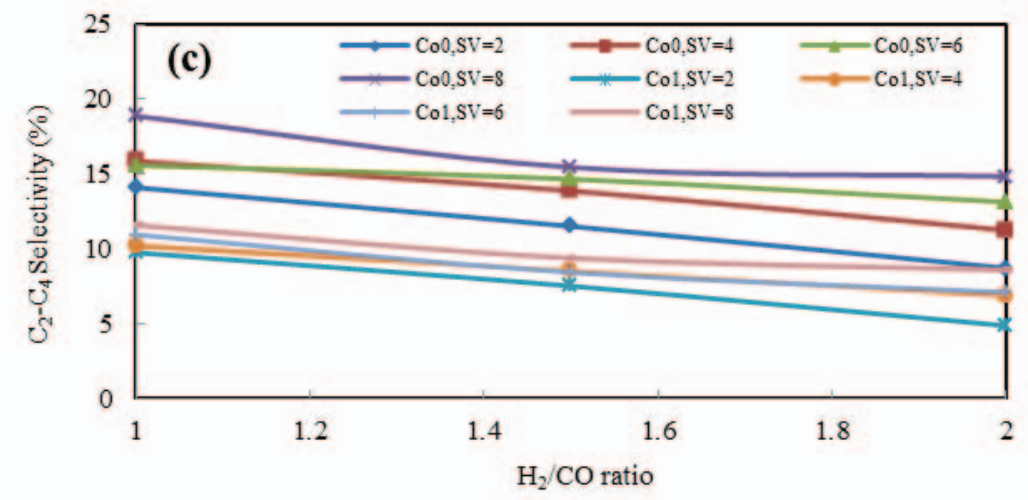

Fig. 5: (c) Effect of $\mathrm{H}_{2} / \mathrm{CO}$ ratio on $\mathrm{C}_{2}-\mathrm{C}_{4}$ selectivity for the Ce-promoted and unpromoted cobalt catalysts at $\mathrm{P}=15 \mathrm{bar}, \mathrm{T}=230^{\circ} \mathrm{C}$ and $\mathrm{SV}=2,4,6$ and $8 \mathrm{~L} / \mathrm{h}$. g cat.

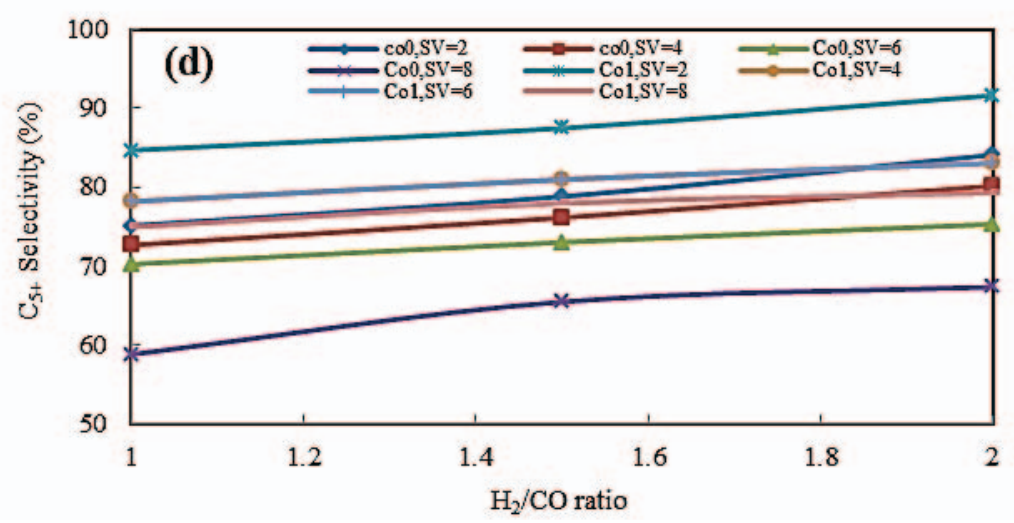

Fig. 5: (d) Effect of $\mathrm{H}_{2} / \mathrm{CO}$ ratio on $\mathrm{C}_{5}+$ selectivity for the Ce-promoted and unpromoted cobalt catalysts at $\mathrm{P}=15 \mathrm{bar}, \mathrm{T}=230^{\circ} \mathrm{C}$ and $\mathrm{SV}=2,4,6$ and $8 \mathrm{~L} / \mathrm{h}$. $\mathrm{g}_{\text {cat. }}$.

\section{CONCLUSION}

In conclusion, the performance of FT synthesis reaction for unpromoted and Cepromoted cobalt-based catalysts was investigated based on space velocity and inlet gas feed ratio reaction conditions. The relevant results demonstrated that the addition of $\mathrm{Ce}$ promoter remarkably enhances the reducibility of cobalt oxides by decreasing the reduction temperature. In addition, Ce promoted Co-based catalysts show a significant $\mathrm{C}_{5+}$ selectivity and $\mathrm{CO}$ conversion ascribed to the high reducibility of Co that provides huge number of active sites for the reactant species. For both Co catalysts, the results exhibited that the reaction properties have strongly affected the catalysts' activity and products' selectivity, consequently, improved $\mathrm{C}_{5+}$ selectivity with low water-gas shift reaction activity were observed at high $\mathrm{H}_{2} / \mathrm{CO}$ ratio and low space velocity. Thus, Ce based Co catalyst is considered to be a suitable candidate for use in the gas to liquid conversion process.

\section{REFERENCES}

[1] Hall KR. (2005) A new gas to liquids (GTL) or gas to ethylene (GTE) technology. Catalysis Today, 106(1-4): 243-246.

[2] Singha RK, Shukla A, Yadav A, Konathala LNS, Bal R. (2017) Effect of metal-support interaction on activity and stability of $\mathrm{Ni}-\mathrm{CeO}_{2}$ catalyst for partial oxidation of methane. Applied Catalysis B: Environmental, 202: 473-488. 
[3] Kim H, Jang W, Yoo S, Shim J, Jeon K, Na H, Lee Y, Jeon B, Bae JW, Roh H.(2018) Low temperature steam reforming of methane using metal oxide promoted $\mathrm{Ni}-\mathrm{Ce}_{0.8} \mathrm{Zr}_{0.2} \mathrm{O}_{2}$ catalysts in a compact reformer. International Journal of Hydrogen Energy, 43(1): 262-270.

[4] Shahhosseini HR, Saeidi S, Najari S, Gallucci F. (2017) Comparison of conventional and spherical reactor for the industrial auto-thermal reforming of methane to maximize synthesis gas and minimize $\mathrm{CO}_{2}$. International Journal of Hydrogen Energy, 42(31): 19798-19809.

[5] Ma W, Jacobs G, Pendyala VRR, Sparks DE, Shafer WD, Thomas GA, MacLennan A, Hu Y, Davis BH. (2018) Fischer-Tropsch synthesis. Effect of $\mathrm{KCl}$ contaminant on the performance of iron and cobalt catalysts. Catalysis Today, 299: 28-36.

[6] Bao B., El-Halwagi M. M., Elbashir N. O.(2010) Simulation, integration, and economic analysis of gas-to-liquid processes. Fuel Processing Technology, 91(7): 703-713.

[7] Mousavi S, Zamaniyan A, Irani M, Rashidzadeh M.(2015) Generalized kinetic model for iron and cobalt based Fischer-Tropsch synthesis catalysts: review and model evaluation. Applied Catalysis A: General, 506: 57-66.

[8] Zhu C, Bollas GM.(2018) Gasoline selective Fischer-Tropsch synthesis in structured bifunctional catalysts. Applied Catalysis B: Environmental, 235: 92-102.

[9] Guo Q, Huang J, Qian W, Zhang H, Ma H, Ying W. (2018) Effect of Lanthanum on Zr$\mathrm{Co} / \gamma-\mathrm{Al}_{2} \mathrm{O}_{3}$ Catalysts for Fischer-Tropsch Synthesis. Catalysis Letters, 148(9): 2789-2798.

[10] Rahmati M, Huang B, Schofield LM, Fletcher TH, Woodfield BF, Hecker WC, Bartholomew CH, Argyle MD. (2018) Effects of Ag promotion and preparation method on cobalt Fischer-Tropsch catalysts supported on silica-modified alumina. Journal of Catalysis, 362: 118-128.

[11] Pedersen EØ, Svenum I-H, Blekkan EA.(2018) Mn promoted Co catalysts for FischerTropsch production of light olefins-An experimental and theoretical study. Journal of Catalysis, 361: 23-32.

[12] Zeng S, Du Y, Su H, Zhang Y. (2011) Promotion effect of single or mixed rare earths on cobalt-based catalysts for Fischer-Tropsch synthesis. Catalysis Communications, 13(1): 6-9.

[13] He L, Zhang Y, Fan M.(2015) Development of composited rare-earth promoted cobalt-based Fischer-Tropsch synthesis catalysts with high activity and selectivity. Applied Catalysis A: General, 505: 276-283.

[14] Pardo TF., Cabrera S, Sanchez DM., Boutonnet M.(2017) Ce-promoted $\mathrm{Co} / \mathrm{Al}_{2} \mathrm{O}_{3}$ catalysts for Fischer-Tropsch synthesis. International journal of hydrogen energy, 42(15): 9754-9765.

[15] de Lima AEP, de Oliveira DC. (2017) In situ XANES study of cobalt in Co-Ce-Al catalyst applied to steam reforming of ethanol reaction. Catalysis Today, 283:104-109.

[16] Trepanier M, Tavasoli A, Dalai AK, Abatzoglou N.(2009) Co, Ru and K loadings effects on the activity and selectivity of carbon nanotubes supported cobalt catalyst in Fischer-Tropsch synthesis. Applied Catalysis A: General, 353(2): 193-202.

[17] Jacobs G, Ji Y, Davis BH, Cronauer D, Kropf AJ, Marshall CL.(2007) Fischer-Tropsch synthesis: temperature programmed EXAFS/XANES investigation of the influence of support type, cobalt loading, and noble metal promoter addition to the reduction behavior of cobalt oxide particles. Applied Catalysis A: General, 333(2): 177-191.

[18] Hilmen A, Schanke D, Holmen A. (1996) TPR study of the mechanism of rhenium promotion of alumina-supported cobalt Fischer-Tropsch catalysts. Catalysis letters, 38(3-4): 143-147.

[19] Chu W, Chernavskii PA, Gengembre L, Pankina GA, Fongarland P, Khodakov AY. (2007) Cobalt species in promoted cobalt alumina-supported Fischer-Tropsch catalysts. Journal of Catalysis, 252(2): 215-230.

[20] Osa AR, Lucas AD, Valverde JL, Romero A, Monteagudo I, Coca P, Sáncheza P.(2011) Influence of alkali promoters on synthetic diesel production over Co catalyst. Catalysis today, 167(1): 96-106.

[21] Osa AR, Lucas AD, Romero A, Valverde JL, Sáncheza P. (2011) Fischer-Tropsch diesel production over calcium-promoted Co/alumina catalyst: Effect of reaction conditions. Fuel Processing Technology, 90(5): 1935-1945. 
[22] Gnanamani MK, Jacobs G, Graham UM, Pendyala VRR, Martinelli M, Lennan AM, Hu Y, Davis BH. (2017) Effect of sequence of $P$ and Co addition over silica for Fischer-Tropsch synthesis. Applied Catalysis A: General, 538: 190-198.

[23] Dry ME.(1999) Fischer-Tropsch reactions and the environment. Applied Catalysis A: General, 189(2): 185-190.

[24] Zhang L, Chu H, Qu H, Zhang Q, Xu H, Cao J, Tang Z, Xuan J. (2018) An investigation of efficient microstructured reactor with monolith $\mathrm{Co} /$ anodic $\gamma$-Al2O3/Al catalyst in FischerTropsch synthesis. International Journal of Hydrogen Energy, 43(6): 3077-3086.

[25] Pendyala VRR, Jacobs G, Bertaux C, Khalid S, Davis BH.(2016) Fischer-Tropsch synthesis: Effect of ammonia on supported cobalt catalysts. Journal of Catalysis, 337: p. 8090 .

[26] Tristantini D ,Lögdberg S, Gevert B, Borg Ø, Holmen A. (2007) The effect of synthesis gas composition on the Fischer-Tropsch synthesis over $\mathrm{Co} / \gamma-\mathrm{Al}_{2} \mathrm{O}_{3}$ and $\mathrm{Co}-\mathrm{Re} / \gamma-\mathrm{Al}_{2} \mathrm{O}_{3}$ catalysts. Fuel processing technology, 88(7): 643-649.

[27] Xu D, Li W, Duan H, Ge Q, Xu H. (2005) Reaction performance and characterization of $\mathrm{Co} / \mathrm{Al}_{2} \mathrm{O}_{3}$ Fischer-Tropsch catalysts promoted with $\mathrm{Pt}, \mathrm{Pd}$ and $\mathrm{Ru}$. Catalysis Letters, 102(34): 229-235.

[28] Storsæter S, Tøtdal B, Walmsley JC, Tanem BS, Holmen A. (2005) Characterization of alumina-, silica-, and titania-supported cobalt Fischer-Tropsch catalysts. Journal of catalysis, 236(1): 139-152.

[29] Visconti CG, Ballova Z, Lietti L, Tronconi E, Zennaro R, Forzatti P. (2010) Advances in Fischer-Tropsch Synthesis. Catalysts and Catalysis, CRC Press Taylor Francis Group, New York. 